\title{
Description of four new species of the genus Kineosporia: Kineosporia succinea sp. nov., Kineosporia rhizophila sp. nov., Kineosporia mikuniensis sp. nov. and Kineosporia rhamnosa sp. nov., isolated from plant samples, and amended description of the genus Kineosporia
}

Japan Collection of Microorganisms, The Institute of Physical and Chemical Research (RIKEN) Wako-shi, Saitama 351 0198, Japan
Takuji Kudo, Keisuke Matsushima, † Takashi Itoh, Junko Sasaki and Ken-ichiro Suzuki
Author for correspondence: Takuji Kudo. Tel: +8148462 1111. Fax: +81484624617 . e-mail: kudo@ulmus.riken.go.jp
Eleven motile spore-bearing actinomycetes were isolated from various plant samples and were studied to determine their taxonomic positions. The isolates showed colony appearance and morphology similar to those of the 'sporedome actinomycetes' previously described by L. G. Willoughby in 1969. Although the isolates showed variety in composition of isomers of 2,6diaminopimelic acid in the cell walls and in whole-cell sugar patterns, all of the isolates were classified in the genus Kineosporia Pagani and Parenti 1978 emend. Itoh et al. 1989 on the basis of their morphological and other chemotaxonomic characteristics, i.e. menaquinone, phospholipid and cellular fatty acid compositions. This assignment to the genus was also supported by a phylogenetic analysis using the 165 rRNA gene sequences. By DNA-DNA hybridization experiment, five genospecies were recognized among the isolates, and one of them showed high levels with the type strain of the type species, Kineosporia aurantiaca, which is the sole member of the genus. These genospecies can be distinguished from each other by their cultural, physiological and biochemical characteristics, and the other four genospecies should be placed into four new species for which the names Kineosporia succinea (type strain $1-273^{\mathrm{T}}=\mathrm{JCM} 9957^{\mathrm{T}}$ ), Kineosporia rhizophila (type strain I$449^{\top}=J C M 9960^{\top}$ ), Kineosporia mikuniensis (type strain $\mathrm{I}^{\mathrm{T}} \mathrm{J63}^{\mathrm{T}}=\mathrm{JCM} 9961^{\mathrm{T}}$ ) and

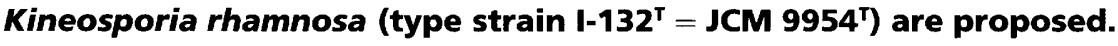

Keywords: Kineosporia succinea, Kineosporia rhizophila, Kineosporia mikuniensis, Kineosporia rhamnosa, actinomycetes

\section{INTRODUCTION}

The genus Kineosporia was first described by Pagani \& Parenti (1978) for a single strain of an aerobic actinomycete that lacked aerial mycelia and formed

\footnotetext{
tPresent address: Discovery Research Laboratories II, Shionogi \& Co., Ltd, Sagisu, Fukushima-ku, Osaka 553-0002, Japan.

Abbreviation: $A_{2} p m$, diaminopimelic acid.

The GenBank/EMBLDDBJ accession numbers for the $16 \mathrm{~S}$ sequences are AB003931 ( $K$. aurantiaca JCM 3230'), AB003932 ( $K$. succinea $1-273^{\top}$ ) $\mathrm{AB} 003933$ ( $K$. rhizophila strain $\left.\mathrm{I}-449^{\mathrm{T}}\right), \mathrm{AB} 003934$ ( $K$. rhamnosa $1-113$ ) and AB003935 (K. rhamnosa $\mathrm{I}-132^{\top}$ ).
}

round-to-pyriform sporangia, each of which contained a single zoospore. The ultrastructural study of this strain by Barnard \& Parenti (1983) supported the light microscopy observation in the original description and showed that the motile spore had a polar tuft of flagella. The genus was also characterized in the original description by the presence of LL-2,6-diaminopimelic acid (LL- $\left.\mathrm{A}_{2} \mathrm{pm}\right)$ and glycine as cell wall components [cell wall type I of Lechevalier \& Lechevalier (1970)] and arabinose, xylose and galactose as wholecell sugars.

Subsequently, Itoh et al. (1989) amended this genus from viewpoints of morphology and chemotaxonomy. 
According to the amended description, the type strain of the type species formed spore clusters on the sporophores and catenated spores around the central projection of the colony as well as single spores covered with a thin sheath that Pagani \& Parenti (1978) called 'sporangia'. Cell walls prepared from the shake-flask culture contained not only LL-A $\mathrm{A}_{2} \mathrm{pm}$ plus glycine but also a significant amount of meso- $\mathrm{A}_{2} \mathrm{pm}$, and the spore fraction collected from the culture on an agar plate contained predominantly meso- $\mathrm{A}_{2} \mathrm{pm}$. The whole-cell sugar components were galactose, glucose, mannose and ribose, but neither arabinose nor xylose, which were reported to be present in the original description (Pagani \& Parenti, 1978), were detected. The major menaquinone and diagnostic phospholipid were MK$9\left(\mathrm{H}_{4}\right)$ and phosphatidylcholine [phospholipid pattern PIII of Lechevalier et al. (1977)], respectively. The cellular fatty acids were composed of normal, monounsaturated, 10-methyl and 2-hydroxy acids, but neither iso- nor anteiso-branched acids were detected. At present, the genus Kineosporia is still constituted by a single species Kineosporia aurantiaca proposed in the original description of this genus.

Furthermore, Itoh et al. (1989) suggested that the morphological and chemical characteristics of the genus Kineosporia are similar to those of so-called 'spore-dome actinomycetes' originally described by Willoughby (1969). Cross and co-workers (Makkar \& Cross, 1982; Cross \& Makkar, 1986; Eke et al., 1989) also isolated actinomycete strains of this group and found their isolates to contain $\mathrm{MK}-9\left(\mathrm{H}_{4}\right)$ as a major menaquinone and to be heterogeneous in composition of $\mathrm{A}_{2} \mathrm{pm}$ isomers. They also showed heterogeneity of their isolates by a numerical phenetic analysis based on morphological and biochemical properties. However, they did not discuss relationship between the "sporedome actinomycetes' and the genus Kineosporia, and did not propose any new taxa for their isolates.

During a search of actinomycetes from various plant samples, we isolated 11 strains showing morphological characteristics similar to a 'spore-dome' structure from leaf litter and sphagnum around hydrosphere and roots. In this paper we report taxonomic characterization and classification of these isolates, and propose the following four new species of the genus Kineosporia: Kineosporia succinea, Kineosporia rhizophila, Kineosporia mikuniensis and Kineosporia rhamnosa.

\section{METHODS}

Bacterial strains and cultivation. Eleven strains isolated from plant samples in Japan (Table 1) were investigated. The leaf, root or sphagnum samples were dried at $28^{\circ} \mathrm{C}$ for at least 1 week and were ground with a blender after adding sterile water. The suspension was incorporated into an agar medium containing $0.2 \mathrm{~g}$ yeast extract (Difco), $50 \mathrm{mg}$ cycloheximide, $50 \mathrm{mg}$ nystatin and $15 \mathrm{~g}$ agar in $1000 \mathrm{ml}$ distilled water ( $\mathrm{pH}$ not adjusted), and this preparation was poured into a Petri dish. After incubation at $28^{\circ} \mathrm{C}$ for more than 2 weeks, colonies that appeared were picked up with a sterile needle under a stereomicroscope and transferred to an agar plate of yeast extract-starch agar containing $2 \mathrm{~g}$ yeast extract, $10 \mathrm{~g}$ soluble starch and $15 \mathrm{~g}$ agar in $1000 \mathrm{ml}$ distilled water ( $\mathrm{pH} 7 \cdot 3$ ). K. aurantiaca JCM $3230^{\mathrm{T}}$ was also used for the comparative study.

These organisms were routinely cultivated on yeast extractstarch agar at $28^{\circ} \mathrm{C}$ for 10 to $14 \mathrm{~d}$ and maintained at $8^{\circ} \mathrm{C}$. Biomass for chemotaxonomic analyses and DNA preparation were obtained from cultures grown in yeast extractglucose broth containing $10 \mathrm{~g}$ yeast extract and $10 \mathrm{~g}$ Dglucose in $1000 \mathrm{ml}$ distilled water $(\mathrm{pH} 7 \cdot 2)$ on a rotary shaker at $30^{\circ} \mathrm{C}$. Spore fraction used for analysis of $\mathrm{A}_{2} \mathrm{pm}$ isomers was obtained as described previously (Itoh et al., 1989).

Morphology. Cultures were grown on yeast extract-starch agar for $14 \mathrm{~d}$ at $28^{\circ} \mathrm{C}$ and observed with a light microscope and a Hitachi S-2400 scanning electron microscope. The specimens for scanning electron microscopy were prepared as described previously (Itoh $e t$ al., 1989).

Cultural, physiological and biochemical characteristics. Cultural characteristics were tested by using 21-d cultures grown at $28{ }^{\circ} \mathrm{C}$ on four selected agar media (Table 2). Colour designations and colour names of colonies were described by comparison with colour chips from the Color Harmony Manual (Jacobson et al., 1958). Decomposition of urea was examined on Christensen agar (Difco) supplemented with $2 \%(\mathrm{w} / \mathrm{v})$ urea, and decomposition of the other compounds was examined on the basal medium of Gordon et al. (1974). Utilization of carbohydrates as sole carbon sources was tested by using neutralized yeast nitrogen base without amino acids (Difco) as a basal medium according to the method of Stevenson (1967). Utilization of organic acids was examined on the defined medium of Gordon et al. (1974). Tolerance to $\mathrm{NaCl}$ was determined by using yeast extractstarch agar supplemented with various concentrations $(0-10 \%, w / v)$ of $\mathrm{NaCl}$ at $28^{\circ} \mathrm{C}$.

Chemotaxonomy. $\mathrm{A}_{2} \mathrm{pm}$ and its isomers (LL and/or meso) in the cell wall peptidoglycan were detected by using TLC as described by Staneck \& Roberts (1974). To determine the composition of the $A_{2} p m$ isomers, a neutral amino acid fraction was separated from a whole-cell hydrolysate and analysed by using HPLC as follows. A whole-cell hydrolysate was loaded onto a column $(5 \times 50 \mathrm{~mm})$ packed with Dowex $50 \mathrm{~W} \times 8\left(200-400 \mathrm{mesh}, \mathrm{H}^{+}\right.$form $)$and washed with $4 \mathrm{ml} \mathrm{H}_{2} \mathrm{O}$. An amino acid fraction was eluted with $3 \mathrm{M}$ $\mathrm{NH}_{4} \mathrm{OH}$. The amino acid fraction was then loaded onto the second column packed with Dowex $1 \times 8$ (200-400 mesh, $\mathrm{CH}_{3} \mathrm{COO}^{-}$form) and a neutral and basic amino acid fraction was eluted with $\mathrm{H}_{2} \mathrm{O}$. This fraction was loaded onto the third column packed with Dowex $50 \mathrm{~W} \times 8\left(200-400\right.$ mesh, $\mathrm{NH}_{4}^{+}$ form) and a neutral amino acid fraction was eluted with $\mathrm{H}_{2} \mathrm{O}$. The neutral amino acid fraction was reacted with a chiral reagent $[(+)-1$-(9-fluorenyl)ethyl chloroformate $]$ and applied to HPLC as described by Einarsson \& Josefsson (1987). The acyl group of muramic acid in peptidoglycan was determined by the method of Uchida \& Aida (1984). Whole-cell sugars were analysed by the TLC method of Staneck \& Roberts (1974) and by the HPLC method of Mikami \& Ishida (1983). 3-O-Methylrhamnose was identified by comparison of $R_{f}$ values on cellulose and silica gel TLC using various solvent systems (Asano et al., 1989b) and of retention times on HPLC with a whole-cell hydrolysate of Catellatospora ferruginea JCM $7544^{\mathrm{T}}$ (Asano et al., 1989b, 1990). Phospholipids were extracted and identified by the method of Minnikin et al. (1984). Methyl esters of cellular fatty acids were prepared by the direct transmethylation method with methanolic hydrochloride (Suzuki \& Komagata, 1983), and were analysed by GLC as described previously (Kudo et al., 1993). Isoprenoid quinones were 
Table 1. List of the isolates used in this study and their sources

\begin{tabular}{|c|c|}
\hline Strain no. & Source \\
\hline $\mathrm{I}-092$ ( = JCM 9952) & Leaves of cat-tail (Typha latifolia), pond in Saitama, Japan \\
\hline I-113 (= JCM 9953) & Leaves of cat-tail (Typha latifolia), pond in Saitama, Japan \\
\hline $\mathrm{I}-132^{\mathrm{T}}\left(=\mathrm{JCM} 9954^{\mathrm{T}}\right)$ & Leaves of cat-tail (Typha latifolia), pond in Saitama, Japan \\
\hline $1-225(=$ JCM 9955) & Fallen leaves, Saitama, Japan \\
\hline $\mathrm{I}-229(=\mathrm{JCM} 9956)$ & Fallen leaves, Saitama, Japan \\
\hline $\mathrm{I}-273^{\mathrm{T}}\left(=\mathrm{JCM} 9957^{\mathrm{T}}\right)$ & Fallen leaves, Saitama, Japan \\
\hline I-279 (= JCM 9958) & Fallen leaves, Saitama, Japan \\
\hline I-281 (= JCM 9959) & Fallen leaves, Saitama, Japan \\
\hline $1-449^{\mathrm{T}}\left(=. \mathrm{ICM} 9960^{\mathrm{T}}\right)$ & Root of galingale (Cyperus microiria), Saitama, Japan \\
\hline $\mathrm{I}-463^{\mathrm{T}}\left(=\mathrm{ICM} 9961^{\mathrm{T}}\right)$ & Sphagnum, Mt Mikuni in Gumma, Japan \\
\hline $\mathrm{I}-468(=\mathrm{JCM} 9962)$ & Sphagnum, Mt Mikuni in Gumma, Japan \\
\hline
\end{tabular}

Table 2. Cultural characteristics of Kineosporia strains

Growth of all strains was good on yeast extract-starch agar and oatmeal agar; growth of all strains was poor on inorganic saltsstarch agar (ISP medium no. 4). Colonies of all strains were colourless on inorganic salts-starch agar (ISP no. 4). There was no diffusible pigment on yeast-malt agar or inorganic salts-starch agar (ISP no. 4). Colour names and codes were taken from the Color Harmony Manual (Jacobson et al., 1958). ISP, International Streptomyces Project (Shirling \& Gottlieb, 1966).

\begin{tabular}{|c|c|c|c|c|c|c|c|c|c|c|c|c|}
\hline \multirow[t]{2}{*}{ Medium } & \multicolumn{3}{|c|}{$K$. aurantiaca } & \multicolumn{4}{|c|}{ K. succinea } & \multicolumn{2}{|c|}{ K. rhizophila } & \multirow{2}{*}{$\frac{\text { K. mikuniensis }}{{\mathrm{I}-463^{\mathrm{T}}}^{\mathrm{T}}}$} & \multicolumn{2}{|c|}{ K. rhamnosa } \\
\hline & $\mathrm{JCM} 3230^{\mathrm{T}}$ & I-225 & I-279 & I-092 & I-229 & $\mathrm{I}^{-273^{\mathrm{T}}}$ & I-281 & $I-449^{T}$ & $\mathrm{I}-\mathbf{4 6 8}$ & & I-113 & $\mathbf{I}-132^{\mathrm{T}}$ \\
\hline \multicolumn{13}{|c|}{ Yeast extract-starch agar } \\
\hline Colour of colony & $\operatorname{Tan}(3 \mathrm{ie})$ & $\begin{array}{l}\text { Light brown } \\
(3 \lg )\end{array}$ & $\begin{array}{l}\text { Light tan } \\
(3 \mathrm{gc})\end{array}$ & $\begin{array}{l}\text { Light amber } \\
\text { (3 ic) }\end{array}$ & $\begin{array}{l}\text { Luggage } \\
\tan (4 \text { ne })\end{array}$ & Amber ( 3 pe) & $\begin{array}{l}\text { Light copper } \\
\text { brown ( } 5 \mathrm{pg})\end{array}$ & $\begin{array}{l}\text { Dusty } \\
\text { orange } \\
\text { (4 lc) }\end{array}$ & $\begin{array}{l}\text { Dusty } \\
\text { orange } \\
(4 \mathrm{lc})\end{array}$ & $\begin{array}{l}\text { Light tan } \\
(3 \mathrm{gc})\end{array}$ & $\begin{array}{l}\text { Light amber } \\
\text { (3 ic) }\end{array}$ & $\begin{array}{l}\text { Amber } \\
(3 \mathrm{lc})\end{array}$ \\
\hline \multicolumn{12}{|c|}{ Yeast-malt agar (ISP medium no. 2) } & None \\
\hline Colour of colony & $\begin{array}{l}\text { Light amber } \\
\text { (3 ic) }\end{array}$ & $\begin{array}{l}\text { Light amber } \\
(3 \mathrm{ic})\end{array}$ & $\begin{array}{l}\text { Light amber } \\
\text { (3 ic) }\end{array}$ & Amber ( $3 \mathrm{lc})$ & Topaz (3 ne) & Topaz (3 ne) & Topaz (3 ne) & $\begin{array}{r}\text { Amber } \\
(3 \mathrm{nc})\end{array}$ & $\begin{array}{r}\text { Amber } \\
(3 \mathrm{nc})\end{array}$ & Amber ( $3 \mathrm{pc})$ & Amber $(3 \mathrm{lc})$ & $\begin{array}{l}\text { Amber } \\
(3 \mathrm{lc})\end{array}$ \\
\hline \multicolumn{13}{|c|}{ Oatmeal agar (ISI' medium no. 3) } \\
\hline Colour of colony & $\begin{array}{l}\text { Light tan } \\
(3 \mathrm{gc})\end{array}$ & $\operatorname{Tan}(3$ ie) & $\begin{array}{l}\text { Light amber } \\
\text { (3 ic) }\end{array}$ & $\begin{array}{l}\text { Light tan } \\
(3 \mathrm{gc})\end{array}$ & $\begin{array}{l}\text { Camel or tan } \\
\text { (3 ie) }\end{array}$ & $\begin{array}{l}\text { Light amber } \\
(3 \mathrm{lc})\end{array}$ & Amber ( 3 pe) & $\begin{array}{l}\text { Dusty } \\
\text { orange } \\
\text { (4 lc) }\end{array}$ & $\begin{array}{l}\text { Dusty } \\
\text { orange } \\
(4 \mathrm{lc})\end{array}$ & $\begin{array}{l}\text { Light tan } \\
(3 \mathrm{gc})\end{array}$ & $\begin{array}{l}\text { Russel } \\
\text { orange } \\
(4 \mathrm{pc})\end{array}$ & $\begin{array}{l}\text { Russet } \\
\text { orange } \\
(4 \mathrm{nc})\end{array}$ \\
\hline Diffusible pigmen & None & None & None & Faint yellow & Faint yellow & Faint yellow & Faint yellow & None & None & Faint yellow & None & None \\
\hline
\end{tabular}

extracted as described by Collins et al. (1984), and analysed by HPLC and a mass spectrometer (Tamaoka et al., 1983; Kudo et al. 1993). Preparation and detection of methyl esters of mycolic acids were carried out as described by Tomiyasu (1982).

Preparation of DNA, DNA base composition and DNA-DNA hybridization. DNA was isolated from biomasses by the method of Saito \& Miura (1963) with minor modification as follows: achromopeptidase crude (Wako), $\mathrm{N}$-acetylmuramidase SG (Seikagaku Kogyo) and lysozyme were used for lysing cells. In case cells failed to be lysed by these enzymes, the cells were freeze-dried and mechanically ground as described by Raeder \& Broda (1985).

The $\mathrm{G}+\mathrm{C}$ content of DNA was determined by the HPLC method of Tamaoka \& Komagata (1984). An equimolar mixture of nucleotides for analysis of DNA base composition (Yamasa Shoyu) was used as the quantitative standard. DNA-DNA relatedness was measured fluorometrically by using the microplate hybridization method described by Ezaki et al. (1989).

$16 \mathrm{~S}$ rDNA sequencing and phylogenetic analysis. The $16 \mathrm{~S}$ rRNA genes of four isolates (strains I-113, I-132, $\mathrm{I}-273^{\mathrm{T}}$ and
I-449 ${ }^{\mathrm{T}}$ ) and $K$. aurantiaca JCM $3230^{\mathrm{T}}$ were sequenced as described previously (Suzuki et al., 1996). These sequences were manually aligned with the selected sequences (Fig. 1) obtained from the Ribosomal Database Project (Maidak et al., 1994). Evolutionary distances were represented by the $K_{\text {nuc }}$ values of Kimura (1980), and a phylogenetic tree was constructed by the neighbour-joining method of Saitou \& Nei (1987) in the PHYLIP package (Felsenstein, 1995). The topology of the resultant unrooted tree was evaluated by bootstrap analyses (Felsenstein, 1985) based on 1000 resamplings.

\section{RESULTS}

\section{Morphological observation}

All of our isolates formed central projections covered with numerous spores, termed 'spore domes' by Willoughby (1969). Single spores borne at the tips of substrate hyphae and spore clusters on a sporophore were also observed at the edges of colonies in some strains as illustrated in the amended description of the genus Kineosporia (Itoh et al., 1989). The colonies of 
T. Kudo and others

Table 3. Physiological and biochemical characteristics of Kineosporia strains

All strains decomposed casein and urea; none decomposed adenine, tyrosine and xanthine. All strains utilized D-cellobiose, D-fructose, D-galactose, D-glucose, maltose, D-mannitol, L-rhamnose, starch and D-xylose; none utilized adonitol, i-erythritol, L-sorbose and xylitol. All of the strains utilized fumalate, malate and succinate; none utilized benzoate, mucate, oxalate and tartrate. All strains produced acid from L-arabinose, D-cellobiose, D-fructose, D-galactose, D-glucose, L-rhamnose, sucrose and $\mathrm{D}$-xylose; none was produced acid from adonitol and i-erythritol.

\begin{tabular}{|c|c|c|c|c|c|c|c|c|c|c|c|c|}
\hline \multirow[t]{3}{*}{ Characteristic } & \multicolumn{3}{|c|}{ K. aurantiaca } & \multicolumn{4}{|c|}{ K. succinea } & \multicolumn{2}{|c|}{ K. rhizophila } & \multirow{3}{*}{$\begin{array}{c}\begin{array}{c}K . \\
\text { mikuniensis }\end{array} \\
\mathrm{I}^{-463^{\mathrm{T}}}\end{array}$} & \multicolumn{2}{|c|}{ K. rhamnosa } \\
\hline & JCM 3230' & I-225 & I-279 & I-092 & I-229 & $\mathrm{I}-273^{\mathrm{T}}$ & I-281 & $I-449^{T}$ & $I-468$ & & I-113 & $I-132^{T}$ \\
\hline & & & & & & & & & & & & \\
\hline \multicolumn{13}{|c|}{ Decomposition of: } \\
\hline DNA & + & + & + & + & + & + & + & + & + & NG & + & + \\
\hline Aesculin & + & + & + & - & - & - & - & - & - & - & - & - \\
\hline Hypoxanthine & - & - & - & + & + & + & + & - & - & - & - & - \\
\hline Testosterone & + & + & + & + & + & + & + & + & + & \pm & - & \pm \\
\hline \multicolumn{13}{|l|}{ Utilization of: } \\
\hline L-Arabinose & + & + & + & + & + & + & + & + & + & + & \pm & \pm \\
\hline D-Arabitol & + & + & + & + & + & + & + & + & + & + & - & - \\
\hline Dulcitol & - & - & - & + & + & + & + & - & - & \pm & - & \pm \\
\hline myo-Inositol & + & + & + & - & + & + & + & - & - & + & + & + \\
\hline D-Lactose & + & + & + & + & + & + & + & + & + & + & - & - \\
\hline D-Melezitose & + & + & + & + & + & + & + & + & + & + & - & - \\
\hline Melibiose & + & + & + & + & + & + & + & + & + & + & - & - \\
\hline $\begin{array}{l}\text { Methyl } \alpha \text {-D- } \\
\text { glucoside }\end{array}$ & - & - & - & - & - & - & - & - & - & + & - & - \\
\hline Raffinose & - & - & - & - & - & - & - & + & + & - & - & \pm \\
\hline D-Ribose & + & + & + & + & + & + & + & + & + & + & - & - \\
\hline Salicin & + & + & + & + & + & + & + & + & + & + & - & - \\
\hline D-Sorbitol & - & - & - & \pm & + & + & + & - & - & - & + & + \\
\hline Sucrose & + & + & + & + & + & + & + & + & + & \pm & \pm & \pm \\
\hline D-Trehalose & + & + & + & + & + & + & + & + & + & + & - & - \\
\hline \multicolumn{13}{|l|}{ Utilization of: } \\
\hline Citrate & + & + & + & - & - & - & - & - & - & - & - & - \\
\hline \multicolumn{13}{|c|}{ Acid production from: } \\
\hline myo-Inositol & - & - & - & - & - & - & - & - & - & + & + & + \\
\hline D-Melezitose & + & + & + & - & - & - & - & + & + & - & - & - \\
\hline D-Sorbitol & - & - & - & - & - & - & - & - & - & - & + & + \\
\hline $\begin{array}{l}\mathrm{NaCl} \text { tolerance } \\
(\%, w / v)\end{array}$ & $<3$ & $<3$ & $<3$ & $<5$ & $<5$ & $<5$ & $<5$ & $<5$ & $<5$ & $<1$ & $<1$ & $<2$ \\
\hline
\end{tabular}

NG, No growth.

all our isolates released motile spores after being transferred to water.

\section{Cultural, physiological and biochemical characteristics}

Cultural characteristics of our isolates and $K$. aurantiaca JCM $3230^{\mathrm{T}}$ are shown in Table 2. They lacked aerial mycelium on any of the agar media and their colonies were usually orange to light brown with a glossy appearance. Strains I-092, I-229, I-273 ${ }^{\mathrm{T}}$, I-281 and $\mathrm{I}-463^{\mathrm{T}}$ produced yellowish diffusible pigments in oatmeal agar, and strains $\mathrm{I}-449^{\mathrm{T}}$ and $\mathrm{I}-468$ produced small amounts of reddish diffusible pigments in yeast extract-starch agar. The results of physiological and biochemical tests are shown in Table 3 .

\section{Chemotaxonomic characteristics}

The TLC analysis of $\mathrm{A}_{2} \mathrm{pm}$ obtained from submerged cultures in shake flasks indicated that the strains used in this study were heterogeneous in composition of the isomers as follows: strains I-225, I-229, I-273 ${ }^{\mathrm{T}}$ and I281 as well as $K$. aurantiaca JCM $3230^{\mathrm{T}}$ contained both LL- and meso-A $\mathrm{pm}$; strains I-092 and I-279 contained LL-A ${ }_{2} \mathrm{pm}$; and strains I-1 13, I-132 $2^{\mathrm{T}}, \mathrm{I}-449^{\mathrm{T}}, \mathrm{I}-463^{\mathrm{T}}$ and $\mathrm{I}-468$ contained meso- $\mathrm{A}_{2} \mathrm{pm}$. The quantitative analysis by HPLC revealed that the strains mainly containing LL and meso isomers also contained meso- and LL$\mathrm{A}_{2} \mathrm{pm}$ as minor components, respectively (Table 4). Spore fractions of all seven strains tested contained meso- $\mathrm{A}_{2} \mathrm{pm}$ as a major component (Table 4). This could be observed even in strain I-092 that contained 
Table 4. Distribution of isomers of diaminopimelic acid $\left(\mathrm{A}_{2} \mathrm{pm}\right)$ and composition of whole-cell sugars in Kineosporia strains

Gal, Galactose; Glc, glucose; Man, mannose; Ara, arabinose; Xyl, xylose; Rib, ribose; Rha, rhamnose; 3-O-M, 3-O-methylrhamnose.

\begin{tabular}{|c|c|c|c|c|c|c|c|c|c|c|c|c|}
\hline \multirow[t]{3}{*}{ Strain } & \multicolumn{4}{|c|}{ Composition of isomers of $A_{2} p m(\%)$ in: } & \multicolumn{8}{|c|}{ Composition of whole-cell sugar } \\
\hline & \multicolumn{2}{|c|}{$\begin{array}{c}\text { Shake-flask } \\
\text { culture }\end{array}$} & \multicolumn{2}{|c|}{ Spore fraction } & \multirow[t]{2}{*}{ Gal } & \multirow[t]{2}{*}{ Glc } & \multirow[t]{2}{*}{ Man } & \multirow[t]{2}{*}{ Ara } & \multirow[t]{2}{*}{ Xyl } & \multirow[t]{2}{*}{ Rib } & \multirow[t]{2}{*}{ Rha } & \multirow[t]{2}{*}{ 3-O-M } \\
\hline & $\mathbf{L L}$ & meso & LL & meso & & & & & & & & \\
\hline \multicolumn{13}{|l|}{ K. aurantiaca } \\
\hline $\mathrm{JCM} 3230^{\mathrm{T}}$ & 49 & 51 & 32 & 68 & + & + & + & - & - & + & - & - \\
\hline $\mathrm{I}-225$ & 45 & 55 & ND & ND & + & + & + & - & - & + & - & - \\
\hline $\mathrm{I}-279$ & 86 & 14 & ND & ND & + & + & + & - & - & + & - & - \\
\hline \multicolumn{13}{|l|}{$K$. succinea } \\
\hline I-092 & 86 & 14 & 30 & 70 & + & + & + & - & - & + & - & - \\
\hline $\mathrm{I}-229$ & 51 & 49 & ND & ND & + & + & + & - & - & + & - & - \\
\hline $\mathrm{I}-273^{\mathrm{T}}$ & 42 & 58 & 21 & 79 & + & + & + & - & - & + & - & - \\
\hline I-281 & 37 & 63 & ND & + & + & + & - & - & + & - & - & \\
\hline \multicolumn{13}{|l|}{ K. rhizophila } \\
\hline $\mathrm{I}-449^{\mathrm{T}}$ & 19 & 81 & 19 & 81 & + & + & + & - & - & + & - & - \\
\hline $\mathrm{I}-468$ & 21 & 79 & ND & ND & + & + & + & - & - & + & - & - \\
\hline \multicolumn{13}{|l|}{ K. mikuniensis } \\
\hline$I-463^{\mathrm{T}}$ & 17 & 83 & 15 & 85 & + & + & + & - & - & + & - & - \\
\hline \multicolumn{13}{|l|}{ K. rhamnosa } \\
\hline $\mathrm{I}-113$ & 17 & 83 & 29 & 71 & + & + & + & - & - & + & + & + \\
\hline $\mathrm{I}-132^{\mathrm{r}}$ & 24 & 76 & 25 & 75 & + & + & + & - & - & + & + & + \\
\hline
\end{tabular}

ND, Not determined.

LL- $\mathrm{A}_{2} \mathrm{pm}$ as a major component in a biomass from the submerged culture. As whole-cell sugars (Table 4), galactose, glucose, mannose and ribose were detected in all of our isolates and in $K$. aurantiaca JCM $3230^{\mathrm{T}}$. In addition to these sugars, two strains I-113 and I$132^{\mathrm{T}}$ contained a significant amount of rhamnose and 3-O-methylrhamnose.

Table 5 shows compositions of cellular fatty acids and menaquinones of the test strains. The cellular fatty acid profiles of all of our isolates and $K$. aurantiaca JCM $3230^{\mathrm{T}}$ were mainly composed of $n-16: 0$ and $n-$ 18:1. A significant amount of 10-methyloctadecanoic acid was also detected in all of the strains except for strains $\mathrm{I}-449^{\mathrm{T}}$ and $\mathrm{I}-468$. The seven strains except I$113, \mathrm{I}-132^{\mathrm{T}}, \mathrm{I}-449^{\mathrm{T}}, \mathrm{I}-463^{\mathrm{T}}$ and $\mathrm{I}-468$ also had a small amount of 2-hydroxy hexadecanoic acid. Neither isonor anteiso-branched acids were observed in any strains. These fatty acid patterns correspond to fatty acid types $1 \mathrm{a}$ (with 10-methyl acid) and $1 \mathrm{~b}$ (without 10methyl acid) of Kroppenstedt (1992). All of the strains contained $\mathrm{MK}-9\left(\mathrm{H}_{4}\right)$ as a predominant isoprenologue, and the retention time in the HPLC analysis suggested that the positions of the hydrogenation were the second and third isoprene units from the 2-methyl-1,4-naphthoquinone moiety [MK-9(II,III-H 4 )]. Phosphatidylcholine was detected in all the strains as a diagnostic phospholipid [phospholipid type PIII of Lechevalier et al. (1977)]. Mycolic acids and $N$-glycolated muramic acid were not detected. The DNA G $+\mathrm{C}$ composition of our isolates and K. aurantiaca JCM $3230^{\mathrm{T}}$ ranged from 68 to $71 \mathrm{~mol} \%$ as shown in Table 6 .

\section{5 rDNA sequence analysis}

The sequences of 1432-1476 nucleotides of the $16 \mathrm{~S}$ rDNAs were determined for K. aurantiaca JCM $3230^{\mathrm{T}}$ and strains $\mathrm{I}-113, \mathrm{I}-132^{\mathrm{T}}, \mathrm{I}-273^{\mathrm{T}}$ and $\mathrm{I}-449^{\mathrm{T}}$. The sequences of the four isolates showed high similarities with that of K. aurantiaca JCM $3230^{\mathrm{T}}$ and the levels of sequence similarities among these strains ranged from $96 \cdot 3$ to $99 \cdot 8 \%$. The data set used for construction of the phylogenetic tree contained 1055 nucleotide positions of each sequence as a result of elimination of gaps and ambiguous nucleotides from the sequences between positions 107 and 1423 [Escherichia coli position number (Brosius et al., 1978)]. The phylogenetic tree constructed by the neighbour-joining method is shown in Fig. 1. K. aurantiaca and our isolates formed a coherent cluster supported by a high bootstrap value (100\%) in the order Actinomycetales and this cluster was loosely but stably related to the genus Kineococcus. The cluster composed of Kineo- 
T. Kudo and others

Table 5. Cellular fatty acid and menaquinone compositions of Kineosporia strains

\begin{tabular}{|c|c|c|c|c|c|c|c|c|c|c|c|c|c|c|c|c|c|c|}
\hline \multirow[t]{3}{*}{ Strain } & \multicolumn{13}{|c|}{ Fatty acid composition (\%) } & \multicolumn{5}{|c|}{ Menaquinone composition (\%) } \\
\hline & \multicolumn{9}{|c|}{ Normal } & \multicolumn{3}{|c|}{ 10-Methyl } & \multirow{2}{*}{$\begin{array}{c}2-\mathrm{OH} \\
2-\mathrm{OH}- \\
16: 0\end{array}$} & \multirow{2}{*}{$\begin{array}{c}\text { MK-8 } \\
\left(\mathrm{H}_{4}\right)\end{array}$} & \multirow{2}{*}{$\begin{array}{r}\text { MK-9 } \\
\left(\mathbf{H}_{0}\right)\end{array}$} & \multirow{2}{*}{$\begin{array}{r}\text { MK-9 } \\
\left(\mathrm{H}_{2}\right)\end{array}$} & \multirow{2}{*}{$\begin{array}{c}\text { MK-9 } \\
\left(\mathrm{H}_{4}\right)\end{array}$} & \multirow{2}{*}{$\begin{array}{r}\text { MK-9 } \\
\left(\mathbf{H}_{6}\right)\end{array}$} \\
\hline & $14: 0$ & $15: 0$ & $16: 0$ & $16: 1$ & $17: 0$ & $17: 1$ & $18: 0$ & $18: 1$ & $19: 0$ & $\begin{array}{c}10-\text { Me- } \\
16: 0\end{array}$ & $\begin{array}{c}\text { 10-Me- } \\
17: 0\end{array}$ & $\begin{array}{c}10 \text {-Me- } \\
18: 0\end{array}$ & & & & & & \\
\hline \multicolumn{19}{|l|}{ K. aurantiaca } \\
\hline JCM $3230^{\mathrm{T}}$ & TR & 2 & 28 & 10 & 1 & $\mathrm{TR}$ & 4 & 21 & 1 & 1 & TR & 28 & 4 & 2 & 2 & 2 & 92 & 3 \\
\hline $\mathrm{I}-225$ & $\mathrm{TR}$ & 1 & 30 & 9 & 1 & TR & 4 & 19 & TR & 1 & TR & 31 & 4 & 4 & 2 & 1 & 91 & 3 \\
\hline 1-279 & TR & 1 & 29 & 8 & 1 & TR & 4 & 22 & 1 & 1 & TR & 28 & 4 & 2 & 2 & 1 & 91 & 4 \\
\hline \multicolumn{19}{|l|}{ K. succinea } \\
\hline I-092 & TR & TR & 26 & 2 & 2 & TR & 7 & 37 & 2 & TR & $\mathrm{TR}$ & 20 & 3 & 4 & 4 & 0 & 92 & 0 \\
\hline $\mathrm{I}-229$ & TR & TR & 26 & 3 & 3 & 2 & 5 & 51 & TR & 0 & TR & 7 & 3 & 3 & 0 & 0 & 95 & 2 \\
\hline $1-273^{\mathrm{T}}$ & TR & TR & 28 & 5 & 2 & $\mathrm{TR}$ & 6 & 43 & 1 & $\mathrm{TR}$ & TR & 12 & 2 & 5 & 2 & 0 & 92 & 1 \\
\hline $1-281$ & $\mathrm{TR}$ & TR & 29 & 4 & 2 & TR & 6 & 40 & $\mathrm{TR}$ & 0 & $\mathrm{TR}$ & 17 & 2 & 2 & 2 & 0 & 94 & 1 \\
\hline \multicolumn{19}{|l|}{ K. rhizophila } \\
\hline $\mathrm{I}-449^{\mathrm{T}}$ & TR & TR & 26 & 5 & 1 & TR & 10 & 57 & TR & 0 & 0 & 0 & 0 & 0 & 1 & 2 & 97 & 0 \\
\hline I-468 & TR & TR & 26 & 6 & 4 & 1 & 8 & 55 & TR & 0 & 0 & 0 & $\mathrm{TR}$ & 1 & 0 & 0 & 99 & 0 \\
\hline \multicolumn{19}{|l|}{ K. mikuniensis } \\
\hline $1-463^{\mathrm{T}}$ & $\mathrm{TR}$ & $\mathrm{TR}$ & 22 & 4 & 11 & 7 & 5 & 38 & TR & TR & 1 & 11 & TR & 4 & 3 & 0 & 92 & 1 \\
\hline \multicolumn{19}{|l|}{ K. rhamnosa } \\
\hline I-113 & 5 & 1 & 21 & TR & 9 & 5 & 12 & 40 & TR & 0 & TR & 6 & 0 & 3 & 7 & 13 & 78 & 0 \\
\hline $\mathrm{I}-132^{\mathrm{T}}$ & 3 & 1 & 17 & 1 & 10 & 4 & 20 & 33 & 1 & 0 & 1 & 8 & 0 & 2 & 6 & 8 & 85 & 1 \\
\hline
\end{tabular}

TR, Trace amounts $(<0 \cdot 5 \%)$.

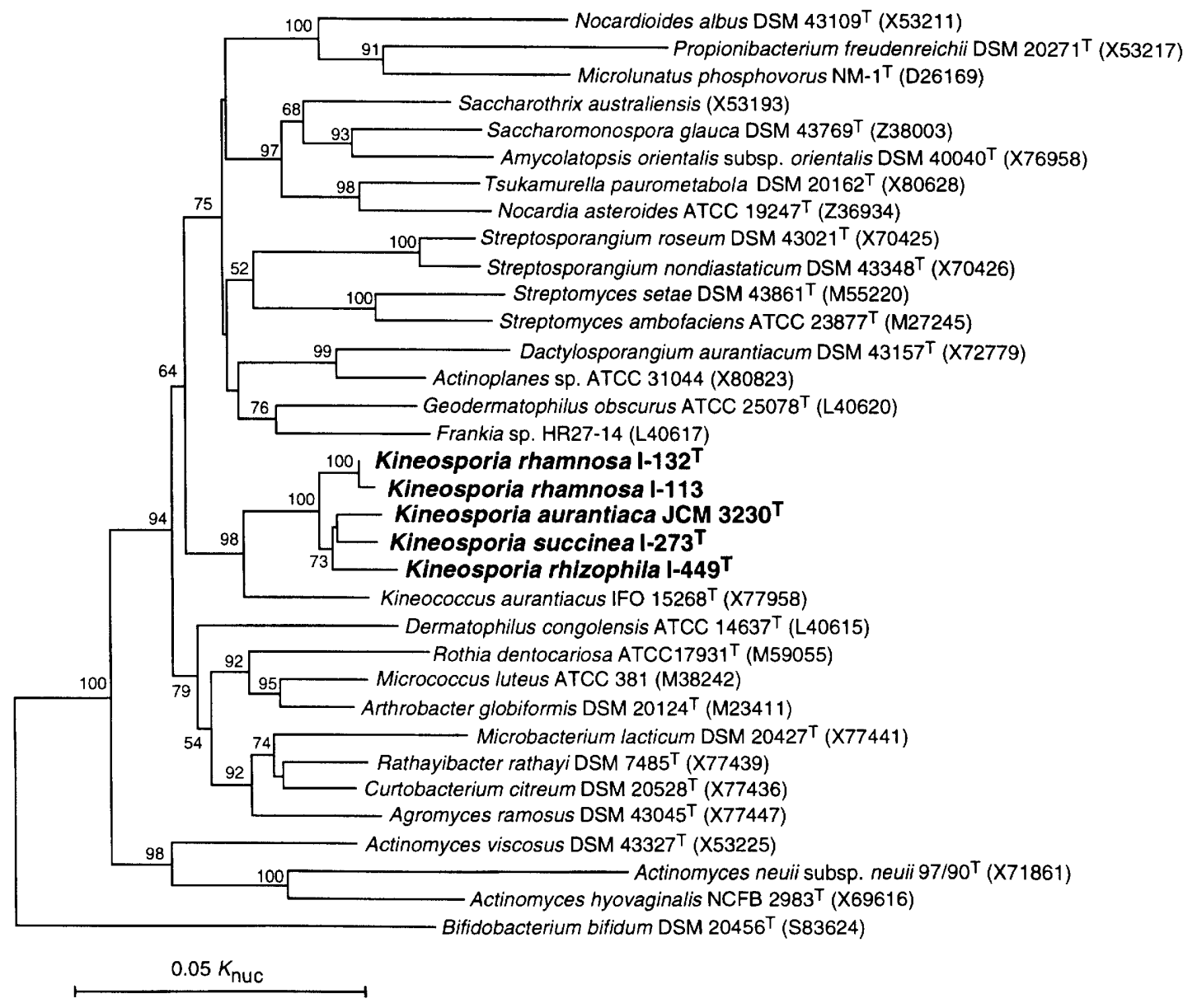

Fig. 1. Phylogenetic relationships of Kineosporia strains and some actinomycete taxa based on 165 rDNA or 165 rRNA sequence comparison. The branching pattern was generated by the neighbour-joining method. The numbers on the tree indicate bootstrap values greater than $50 \%$. The numbers in parentheses are accession numbers for the DDBJ/EMBL/GenBank nucleotide sequence databases. 
Table 6. DNA base composition and relatedness among Kineosporia strains

\begin{tabular}{|c|c|c|c|c|c|c|c|c|c|c|c|c|c|}
\hline \multirow[t]{2}{*}{ Strain } & \multirow{2}{*}{$\begin{array}{l}\mathbf{G}+\mathbf{C} \\
\text { content } \\
(\mathbf{m o l} \%)\end{array}$} & \multicolumn{12}{|c|}{ Percentage DNA complementarity with labelled DNA from: } \\
\hline & & JCM 3230 ${ }^{\mathrm{T}}$ & I-225 & I-279 & I-092 & I-229 & $\mathrm{I}^{-273^{\mathrm{T}}}$ & I-281 & $I-449^{T}$ & I-468 & $\mathrm{I}-463^{\mathrm{T}}$ & I-113 & I-132 \\
\hline \multicolumn{14}{|l|}{ K. aurantiaca } \\
\hline $\mathrm{JCM} 3230^{\mathrm{T}}$ & $69 \cdot 5$ & 100 & 93 & 93 & 37 & 33 & 34 & 35 & 40 & 41 & 38 & 23 & 19 \\
\hline $\mathrm{I}-225$ & $69 \cdot 1$ & 94 & 100 & 98 & 32 & 30 & 31 & 32 & 37 & 35 & 34 & 21 & 17 \\
\hline $\mathrm{I}-279$ & $69 \cdot 6$ & 94 & 93 & 100 & 28 & 31 & 30 & 30 & 33 & 36 & 33 & 21 & 19 \\
\hline \multicolumn{14}{|l|}{ K. succined } \\
\hline $\mathrm{I}-092$ & $70 \cdot 8$ & 26 & 33 & 31 & 100 & 67 & 62 & 62 & 42 & 37 & 37 & 21 & 18 \\
\hline $\mathrm{I}-229$ & $70 \cdot 5$ & 34 & 37 & 34 & 77 & 100 & 101 & 104 & 39 & 40 & 38 & 23 & 22 \\
\hline $\mathrm{I}-273^{\mathrm{T}}$ & $70 \cdot 7$ & 35 & 36 & 37 & 79 & 105 & 100 & 109 & 42 & 43 & 37 & 24 & 24 \\
\hline $\mathrm{I}-281$ & $70 \cdot 3$ & 20 & 29 & 27 & 62 & 92 & 89 & 100 & 38 & 31 & 33 & 19 & 17 \\
\hline \multicolumn{14}{|l|}{ K. rhizophila } \\
\hline $\mathrm{I}-449^{N}$ & $70 \cdot 0$ & 23 & 32 & 30 & 35 & 33 & 34 & 34 & 100 & 99 & 36 & 19 & 20 \\
\hline $\mathrm{I}-468$ & $70 \cdot 2$ & 30 & 30 & 28 & 36 & 31 & 31 & 33 & 90 & 100 & 38 & 20 & 18 \\
\hline \multicolumn{14}{|l|}{ K. mikuni'nsis } \\
\hline $\mathrm{I}-463^{\mathrm{T}}$ & $69 \cdot 4$ & 36 & 35 & 34 & 39 & 33 & 32 & 36 & 40 & 42 & 100 & 21 & 17 \\
\hline \multicolumn{14}{|l|}{ K. rhamnosa } \\
\hline I-113 & $68 \cdot 7$ & 12 & 20 & 16 & 22 & 20 & 19 & 18 & 22 & 19 & 20 & 100 & 92 \\
\hline $\mathrm{I}-132^{\mathrm{T}}$ & $68 \cdot 3$ & 12 & 17 & 14 & 20 & 19 & 19 & 18 & 21 & 19 & 19 & 87 & 100 \\
\hline
\end{tabular}

sporia aurantiaca, our isolates and Kineococcus aurantiacus was not affiliated in any suborder proposed by Stackebrandt et al. (1997).

\section{DNA-DNA hybridization}

The DNA-DNA hybridization experiments revealed that five genospecies were recognized among the 11 isolates (Table 6). One of them composed of strains I225 and I-279 showed high levels of DNA relatedness (93-94\%) with $K$. aurantiaca JCM $3230^{\mathrm{T}}$, while members of the other four genospecies were $41 \%$ or less related to $K$. aurantiaca JCM $3230^{\mathrm{T}}$. Levels of DNA relatedness among strains within the same genospecies were more than $62 \%$, and levels among the five genospecies ranged from 12 to $42 \%$.

\section{DISCUSSION}

According to the amended description of the genus Kineosporia (Itoh et al., 1989), this genus has the following morphological characteristics: colonies lack aerial mycelia and form central (dome) projections having a conical crateriform or cerebriform shape; numerous zoospores are released from the surfaces of colonies immersed in water; the central projections seem to show hyphae radiating toward the surfaces; catenated spores are formed around the central projections; single spores are attached to the ends of vegetative hyphae at the edges of colonies; and some colonies have small dome projections that bear a number of spore clusters with sporophores, which are bunched together in the agar. These characteristics of sporulation correspond to those of spore domes and spore heads described by Willoughby (1969) and are consistent with those of our isolates.
The chemotaxonomic characteristics of our isolates, with the exception of the ratio of isomers of $\mathrm{A}_{2} \mathrm{pm}$ in the cell wall and whole-cell sugar patterns, are almost homogeneous and coincide with those of the genus Kineosporia. The menaquinone composition of our isolates [MK-9 $\left.\left(\mathrm{H}_{4}\right)\right]$ also agreed with the result of Cross \& Makkar (1986) on their spore dome isolates. Strains I-449 ${ }^{\mathrm{T}}$ and I-468 do not have 10-methyloctadecanoic acid in their fatty acid composition, while most strains including $K$. aurantiaca JCM $3230^{\mathrm{T}}$ have a significant amount of this acid. However, such a difference is not substantial for classification because 10 -methylation of fatty acids secondarily occurs in the corresponding monounsaturated fatty acids, e.g. 10methyloctadecanoic acid is derived from octadecenoic acid) (Suzuki \& Komagata, 1983).

Diamino acids in cell walls have historically been one of the most important criteria for classification of actinomycetes and related bacteria at the genus level. However, the strains used in this study showed variety in the ratio of $\mathrm{A}_{2} \mathrm{pm}$ isomers and can be classified into LL-plus-meso type (strains I-225, I-229, I-273 ${ }^{\mathrm{T}}$ and I281 and JCM $3230^{\mathrm{T}}$ ), LL type (strains I-092 and I-279) and meso type (strains I-113, I-132 $2^{\mathrm{T}}, \mathrm{I}-449^{\mathrm{T}}, \mathrm{I}-463^{\mathrm{T}}$ and I-468). Cross \& Makkar (1986) and Eke et al. (1989) also reported heterogeneity of their spore-dome isolates that contained LL- or meso-A ${ }_{2}$ pm or both of the two isomers. Eke et al. (1989) compared the isomers derived from shake-flask cultures and fractionated spores and substrate mycelia to explain this phenomenon. They indicated that the spore fraction had cell walls that contained meso- $\mathrm{A}_{2} \mathrm{pm}$ and the substrate mycelium fraction contained the LL isomer. From this result they concluded that the proportions of the two isomers detected in shake-flask cultures varies with 
incubation time and the strain used. In our results of the $A_{2} p m$ analyses, there were three patterns in composition of the isomers. Two patterns of them, i.e. the LL-plus-meso type and the LL type, can be explained by the interpretation of Eke et al. (1989), and this is supported by our result that a large amount of the meso isomer was detected in spore fraction of strain I092 predominantly containing LL-A ${ }_{2} \mathrm{pm}$ in its shakeflask culture. Therefore, the amount of $m e s o-\mathrm{A}_{2} \mathrm{pm}$ in shake-flask cultures of the LL-plus-meso type and the LL type depends on the degree of sporulation and is influenced by culture condition or ability to sporulate, and there was no substantial difference between the two types. This is also supported by the result of our DNA-DNA hybridization experiment (Table 6). For example, strain I-279 of the LL type showed high similarity with $K$. aurantiaca JCM $3230^{\mathrm{T}}$ and strain I225 of the LL-plus-meso type. On the other hand, it is difficult to apply the interpretation mentioned above to strains of the meso type because proportion of spores to mycelia in the liquid medium cannot be so high as indicated by the amount of meso- $\mathrm{A}_{2} \mathrm{pm}$. In fact, microscopic observation indicated that mycelia were much more dominant in the liquid cultures of the strains of the meso type. Therefore, it is proper to consider that a large amount of the meso isomer exists in the substrate mycelia of the strains of the meso type. The result of our DNA-DNA hybridization experiment (Table 6) shows that the five strains of the meso type are clearly separated from strains of the LL-plusmeso and LL types.

K. aurantiaca JCM $3230^{\mathrm{T}}$ and our isolates contained galactose, glucose, mannose and ribose as whole-cell sugars in common, which are not considered to be diagnostic for actinomycete taxonomy. On the other hand, strains I-113 and I-132 ${ }^{\mathrm{T}}$, which had meso- $\mathrm{A}_{2} \mathrm{pm}$ as a major component of the cell walls, contained rhamnose and 3-O-methylrhamnose in the whole cells. Rhamnose is characteristic of the genera Saccharothrix (Labeda et al., 1984; Grund \& Kroppenstedt, 1989) and Kutzneria (Stackebrandt et al., 1994), and 3-Omethylrhamnose was detected in cell walls of some species of the genus Catellatospora (Asano et al., 1989a, b). The genus Catellatospora (Asano \& Kawamoto, 1986; Asano et al., 1989a) can be divided into two groups, i.e. members of one group contain menaquinones with nine isoprene units (Catellatospora (itrea and Catellatospora tsunoense) and members of the other group contain menaquinones with 10 isoprene units (Catellatospora ferruginea and Catellatospora matsumotoense). 3-O-Methylrhamnose was detected in members of only the two species of the latter group. The recent phylogenetic study (Koch et al., 1996) suggested the possibility that these two groups are separated at the genus level, and this means that 3$O$-methylrhamnose may be used as a criterion at the genus level.

To evaluate differences in compositions of the $\mathrm{A}_{2} \mathrm{pm}$ isomers and in presence or absence of rhamnose and 3$O$-methylrhamnose, a phylogenetic analysis of our isolates and $K$. aurantiaca JCM $3230^{\mathrm{T}}$ based on $16 \mathrm{~S}$ rDNA sequences was performed by using the following strains: strains JCM $3230^{\mathrm{T}}$ and $\mathrm{I}-273^{\mathrm{T}}$ were used as representatives of the LL-plus-meso type, strains I$113, \mathrm{I}-132^{\mathrm{T}}$ and $\mathrm{I}-449^{\mathrm{T}}$ were representatives of the meso type, and strains $\mathrm{I}-113$ and $\mathrm{I}-132^{\mathrm{T}}$ were also representatives of the rhamnose- and 3-O-methylrhamnose-containing group. The sequences among these strains showed high similarity ranging from $96 \cdot 3$ to $99.8 \%$. Fig. 1 shows that strains of the meso type and the rhamnose- and 3-O-methylrhamnose-containing strains form a coherent cluster with $K$. aurantiaca JCM $3230^{\mathrm{T}}$ and strain $\mathrm{I}-273^{\mathrm{T}}$, supported by a high bootstrap value $(100 \%)$. On the basis of morphology and chemotaxonomy mainly based on the lipid profiles, and the phylogenetic analysis, we conclude that all of our isolates should be classified in the genus Kineosporia.

Itoh et al. (1989) described in their emendation of the genus Kineosporia that $\mathrm{LL}-$ and meso- $\mathrm{A}_{2} \mathrm{pm}$ were localized in the mycelia and in the spores, respectively, and did not refer to the presence of strains containing rhamnose and 3-O-methylrhamnose as whole-cell sugars. Therefore, further emendation of the genus Kineosporia as proposed below is necessary for placing the strains of the meso type and the rhamnose- and 3$O$-methylrhamnose-containing strains into the genus Kineosporia.

The 16S rDNA analysis in this study also suggested the phylogenetic position of the genus Kineosporia. Stackebrandt et al. (1997) classified almost all the genera constituting the order Actinomycetales under the 10 suborders and 30 families based on the phylogenetic analyses of the $16 \mathrm{~S} \mathrm{rRNA} / \mathrm{rDNA}$ sequence data, but the six genera, including Kineosporia and Kineococcus, were excluded from the classification system proposed by them owing to uncertainty of the phylogenetic positions. Fig. 1 indicates that the genera Kineosporia and Kineococcus form a cluster with a high bootstrap value $(98 \%)$ and do not belong to any suborder previously described. Furthermore, the evolutionary distance between the two genera seems to be distant enough to separate them at the family level. Valid descriptions of a new suborder and new families for these genera will require confirming the phylogenetic position by using some algorithms other than the neighbour-joining method and searching for signature nucleotides that distinguish the Kineosporia Kineococcus cluster and between these two genera.

Classification at the species level was based on results of the DNA-DNA hybridization experiment and cultural, physiological and biochemical characterization. As shown in Table 6, our isolates and Kineosporia aurantiaca JCM $3230^{\mathrm{T}}$ were classified into five genospecies. Since the first one contains strain JCM $3230^{\mathrm{T}}$, strains I-225 and I-279 should be identified as $K$. aurantiaca. The second including four strains consists of the rest of LL-plus-meso and LL types. The third to fifth are constituted by strains of the meso type, and two strains of the fifth one are the rhamnose 
and 3-O-methylrhamnose-containing strains. These five genospecies can be clearly distinguished by their phenotypic characteristics as shown in Tables 2 and 3 , and this means that each genospecies should be considered an independent species. Therefore, we propose four new species of the genus Kineosporia, Kineosporia succinea sp. nov., Kineosporia rhizophila sp. nov.. Kineosporia mikuniensis sp. nov. and Kineosporia rhamnosa sp. nov., for the second to fifth genospecies, respectively.

\section{Amended description of the genus Kineosporia Pagani and Parenti 1978}

The amended description below is based on the previous amended description (Itoh et al., 1989) except for compositions of $\mathrm{A}_{2} \mathrm{pm}$ isomers and whole-cell sugars.

Aerobic, Gram-positive and non-acid-fast. Colonies on agar medium lack aerial mycelia, form central projections with radiating vegetative hyphae, and are occasionally accompanied by bunches of spore clusters in the agar. Mature colonies have a gelatinous matrix which confers a glossy appearance. Spores, which are spherical to ovoid or pyriform with a long axis of 1-2 $\mu \mathrm{m}$, are catenated around the central projection or are located singly or in aggregates at the tips of hyphae. The spores are motile with polar tufts of flagella. The peptidoglycan contains almost equivalent LL- and meso-A $\mathrm{A}_{2} \mathrm{pm}$, or mainly LL- or meso-A $\mathrm{A}_{2} \mathrm{pm}$. The spores contain predominantly meso- $\mathrm{A}_{2} \mathrm{pm}$ accompanied by glycine. The whole-cultured organism contains galactose, glucose, mannose and ribose. In addition to these sugars, rhamnose and 3-O-methylrhamnose may be present. Phosphatidylcholine is a diagnostic phospholipid, and MK-9(II,III- $\left.\mathrm{H}_{4}\right)$ is present as a major component. The cellular fatty acid profile is composed mainly of $n$-hexadecanoic acid and n-octadecenoic acid, and lacks iso- and anteisobranched fatty acids. 10-Methyl octadecanoic acid and 2-hydroxy hexadecanoic acids are also present in some strains. Mycolic acids are absent. The $\mathrm{G}+\mathrm{C}$ content of the DNA ranges from 69 to $71 \mathrm{~mol} \%$. The type species is $K$. aurantiaca.

\section{Description of Kineosporia succinea sp. nov.}

Kineosporia succinea (suc.ci.nea. L. fem. adj. succinea amber-coloured).

Substrate mycelia are orange to light brown (especially on yeast extract-starch agar). Produces faint yellowish diffusible pigments on oatmeal agar. Decomposes casein, DNA, hypoxanthine, testosterone and urea, but not adenine, aesculin, tyrosine and xanthine. Utilizes L-arabinose, D-arabitol, D-cellobiose, dulcitol, D-fructose, D-galactose, D-glucose, D-lactose, maltose, D-mannitol, D-melezitose, melibiose, L-rhamnose, Dribose, salicin, starch, sucrose, D-trehalose and Dxylose as a sole carbon source, but not adonitol, ierythritol. methyl $\alpha$-D-glucoside, raffinose, L-sorbose and xylitol. Utilizes fumaric acid, L-malic acid and succinic acid, but not benzoic acid, citric acid, mucic acid, oxalic acid and L-tartaric acid. Produces acids from L-arabinose, D-cellobiose, D-fructose, D-galactose, D-glucose, L-rhamnose, sucrose and Dxylose, but not adonitol, i-erythritol, myo-inositol, Dmelezitose and D-sorbitol. Tolerates up to $4 \%(\mathrm{w} / \mathrm{v})$ $\mathrm{NaCl}$. Mesophilic. The $\mathrm{G}+\mathrm{C}$ content of the DNA is $70-71 \mathrm{~mol} \%$. Contains almost the same amount of LLand meso-diaminopimelic acid or a major amount of LL-diaminopimelic acid in the cell wall. Contains neither rhamnose nor 3-O-methylrhamnose in the whole-cell hydrolysate. The type strain is strain I- $273^{\mathrm{T}}$ $\left(=\mathrm{JCM} 9957^{\mathrm{T}}\right)$.

\section{Description of Kineosporia rhizophila sp. nov.}

Kineosporia rhizophila (rhi.zo.phi'la. Gr. n. rhizoma root; Gr. adj. philus loving; M.L. fem. adj. rhizophila root-loving).

Substrate mycelia are orange to light brown (especially on yeast extract-starch agar). Produces faint reddish diffusible pigments on yeast extract-starch agar. Decomposes casein, DNA, testosterone and urea, but not adenine, aesculin, hypoxanthine, tyrosine and xanthine. Utilizes L-arabinose, D-arabitol, D-cellobiose, Dfructose, D-galactose, D-glucose, D-lactose, maltose, Dmannitol, D-melezitose, melibiose, raffinose, L-rhamnose, D-ribose, salicin, starch, sucrose, D-trehalose and $\mathrm{D}$-xylose as a sole carbon source, but not adonitol, dulcitol, i-erythritol, myo-inositol, methyl $\alpha$-Dglucoside, D-sorbitol, L-sorbose and xylitol. Utilizes fumaric acid, L-malic acid and succinic acid, but not benzoic acid, citric acid, mucic acid, oxalic acid and L-tartaric acid. Produces acids from L-arabinose, D-cellobiose, D-fructose, D-galactose, D-glucose, Dmelezitose, L-rhamnose, sucrose and D-xylose, but not adonitol, i-erythritol, myo-inositol and D-sorbitol. Tolerates up to $4 \%(\mathrm{w} / \mathrm{v}) \mathrm{NaCl}$. Mesophilic. The $\mathrm{G}+\mathrm{C}$ content of the DNA is $70 \mathrm{~mol} \%$. Contains a major amount of meso-diaminopimelic acid in the cell wall. Contains neither rhamnose nor 3-O-methylrhamnose in the whole-cell hydrolysate. The type strain is strain $\mathrm{I}-449^{\mathrm{T}}\left(=\mathrm{JCM} 9960^{\mathrm{T}}\right)$.

\section{Description of Kineosporia mikuniensis sp. nov.}

Kineosporia mikuniensis (mi.ku.ni.en'sis. M.L. fem. adj. mikuniensis derivative of Mt Mikuni, Gumma Prefecture, Japan, the location from which the type strain was isolated).

Substrate mycelia are orange to light brown (especially on yeast extract-starch agar). Produces faint yellowish diffusible pigments in oatmeal agar. Decomposes casein and urea, but not aesculin, hypoxanthine, tyrosine and xanthine. Utilizes L-arabinose, D-arabitol, D-cellobiose, D-fructose, D-galactose, D-glucose, myoinositol, D-lactose, maltose, D-mannitol, D-melezitose, melibiose, methyl $\alpha$-D-glucoside, L-rhamnose, Dribose, salicin, starch, D-trehalose and D-xylose as a 
sole carbon source, but not adonitol, i-erythritol, raffinose, D-sorbitol, L-sorbose and xylitol. Utilizes fumaric acid, L-malic acid and succinic acid, but not benzoic acid, citric acid, mucic acid, oxalic acid and Ltartaric acid. Produces acids from L-arabinose, Dcellobiose, D-fructose, D-galactose, D-glucose, myoinositol, L-rhamnose, sucrose and D-xylose, but not adonitol, i-erythritol, D-melezitose and D-sorbitol. Does not grow in the presence of $1 \%(\mathrm{w} / \mathrm{v}) \mathrm{NaCl}$. Mesophilic. The $\mathrm{G}+\mathrm{C}$ content of the DNA is $69 \mathrm{~mol} \%$. Contains a major amount of meso-diaminopimelic acid in the cell wall. Contains neither rhamnose nor 3-O-methylrhamnose in the whole-cell hydrolysate. The type strain is strain I-463 $3^{\mathrm{T}}\left(=\mathrm{JCM} 9961^{\mathrm{T}}\right)$. Monotypic.

\section{Description of Kineosporia rhamnosa sp. nov.}

Kineosporia rhamnosa (rham.no'sa. M.L. fem. adj. rhamnosa pertaining to rhamnose).

Substrate mycelia are orange to light brown (especially on yeast extract-starch agar). Does not produce any diffusible pigments in yeast extract-starch and oatmeal agar media. Decomposes casein, DNA and urea, but not aesculin, hypoxanthine, tyrosine and xanthine. Utilizes D-cellobiose, D-fructose, D-galactose, Dglucose, myo-inositol, maltose, D-mannitol, Lrhamnose, D-sorbitol, starch and D-xylose as a sole carbon source, but not adonitol, D-arabitol, i-erythritol, D-lactose, D-melezitose, melibiose, methyl $\alpha$-Dglucoside, D-ribose, salicin, L-sorbose, D-trehalose and xylitol. Utilizes fumaric acid, L-malic acid and succinic acid, but not benzoic acid, citric acid, mucic acid, oxalic acid and L-tartaric acid. Produces acids from L-arabinose, D-cellobiose, D-fructose, D-galactose, Dglucose, myo-inositol, L-rhamnose, D-sorbitol, sucrose and D-xylose, but not adonitol, i-erythritol and Dmelezitose. Does not grow in the presence of $2 \%(\mathrm{w} / \mathrm{v})$ $\mathrm{NaCl}$. Mesophilic. The $\mathrm{G}+\mathrm{C}$ content of the DNA is 68-69 mol\%. Contains a major amount of mesodiaminopimelic acid in the cell wall. Contains rhamnose and 3-O-methylrhamnose in the whole-cell hydrolysate. The type strain is strain I-132 ${ }^{\mathrm{T}}\left(=\mathrm{JCM} 9954^{\mathrm{T}}\right)$.

\section{ACKNOWLEDGEMENTS}

We thank M. Chijimatsu, Division of Biomolecular Characterization, The Institute of Physical and Chemical Research (RIKEN), for analysing composition of isomers of diaminopimelic acid by the HPLC method.

\section{REFERENCES}

Asano, K. \& Kawamoto, I. (1986). Catellatospora, a new genus of the Actinomycetales. Int J Syst Bacteriol 36, 512-517.

Asano, K., Masunaga, I. \& Kawamoto, I. (1989a). Catellatospora matsumotoense sp. nov. and C. tsunoense sp. nov., actinomycetes found in woodland soils. Int J Syst Bacteriol 39, 309-313.

Asano, K., Sano, H., Masunaga, I. \& Kawamoto, I. (1989b). 3- $O-$ Methylrhamnose: identification and distribution in Catellatospora species and related actinomycetes. Int $J$ Syst Bacteriol $39,56-60$.
Asano, K., Masunaga, I., Kawamoto, I. \& Ohta, S. (1990). Cellwall teichuronic acid containing 3-O-methylrhamnose and glucuronic acid in Catellatospora ferruginea, a soil actinomycete. Agric Biol Chem 54, 1235-1240.

Barnard, S. D. \& Parenti, F. (1983). Ultrastructural morphology of the genus Kineosporia. Curr Microbiol 8, 173-176.

Brosius, J., Palmer, M. L., Kennedy, P. J. \& Noller, H. F. (1978). Complete nucleotide sequence of a $16 \mathrm{~S}$ ribosomal RNA gene from Escherichia coli. Proc Natl Acad Sci USA 75, 4801-4805.

Collins, M. D., Faulkner, M. \& Keddie, M. (1984). Menaquinone composition of some sporeforming actinomycetes. Syst Appl Microbiol 5, 20-29.

Cross, T. \& Makkar, N. S. (1986). Spore dome actinomycetes. In Biological, Biochemical and Biomedical Aspects of Actinomycetes, pp. 579-581. Edited by G. Szabó, S. Biró \& M. Goodfellow. Budapest: Akadémiai Kiadó.

Einarsson, S. \& Josefsson, B. (1987). Separation of amino acid enantiomers and chiral amines using precolumn derivatization with (+)-1-(9-fluorenyl)ethyl chloroformate and reversedphase liquid chromatography. Anal Chem 59, 1191-1195.

Eke, M. A., Alderson, G. \& Cross, T. (1989). An actinomycete that changes wall composition during sporulation. Lett Appl Microbiol 9, 1-4.

Ezaki, T., Hashimoto, Y. \& Yabuuchi, E. (1989). Fluorometric deoxyribonucleic acid-deoxyribonucleic acid hybridization in microdilution wells as an alternative to membrane filter hybridization in which radioisotopes are used to determine genetic relatedness among bacterial strains. Int $J$ Syst Bacteriol 39, 224-229.

Felsenstein, J. (1985). Confidence limits on phylogenies: an approach using the bootstrap. Evolution 39, 783-791.

Felsenstein, J. (1995). PHYLIP (phylogeny inference package), version 3.57c. Seattle: Department of Genetics, University of Washington.

Gordon, R. E., Barnett, D. A., Handerhan, J. E. \& Pang, C. H.-N. (1974). Nocardia coeliaca, Nocardia autotrophica, and the nocardin strain. Int $J$ Syst Bacteriol 24, 54-63.

Grund, E. \& Kroppenstedt, R. M. (1989). Transfer of five Nocardiopsis species to the genus Saccharothrix Labeda et al. 1984. Syst Appl Microbiol 12, 267-274.

Itoh, T., Kudo, T., Parenti, F. \& Seino, A. (1989). Amended description of the genus Kineosporia, based on chemotaxonomic and morphological studies. Int J Syst Bacteriol 39, 168-173.

Jacobson, E., Grauville, W. C. \& Fogs, C. E. (1958). Color Harmony Manual, 4th edn. Chicago: Container Corporation of America.

Kimura, M. (1980). A simple method for estimating evolutionary rates of base substitutions through comparative studies of nucleotide sequences. $J$ Mol Evol 16, 111-120.

Koch, C., Kroppenstedt, R. M., Rainey, F. A. \& Stackebrandt, E. (1996). 16S ribosomal DNA analysis of the genera Micromonospora, Actinoplanes, Catellatospora, Catenuloplanes, Couchioplanes, Dactylosporangium, and Pilimelia and emendation of the family Micromonosporaceae. Int J Syst Bacteriol 46, 765-768.

Kroppenstedt, R. M. (1992). The genus Nocardiopsis. In The Prokaryotes, vol. II, pp. 1139-1156. Edited by A. Balows, H. G. Trüper, M. Dworkin, W. Harder \& K.-H. Schleifer. New York: Springer.

Kudo, T., Itoh, T., Miyadoh, S., Shomura, T. \& Seino, A. (1993). Herbidospora gen. nov., a new genus of the family Streptosporangiaceae Goodfellow et al. 1990. Int J Syst Bacteriol 43, 319-328. 
Labeda, D. P., Testa, R. T., Lechevalier, M. P. \& Lechevalier, H. A. (1984). Saccharothrix: a new genus of the Actinomycetales related to Nocardiopsis. Int J Syst Bacteriol 34, 426-431.

Lechevalier, M. P. \& Lechevalier, H. (1970). Chemical composition as a criterion in the classification of aerobic actinomycetes. Int J Syst Bacteriol 20, 435-443.

Lechevalier, M. P., De Bievre, C. \& Lechevalier, H. (1977). Chemotaxonomy of aerobic actinomycetes: phospholipid composition. Biochem Syst Ecol 5, 249-260.

Maidak, B. L., Larsen, N., McCaughey, M. J., Overbeek, R., Olsen, G. J., Fogel, K., Blandy, J. \& Woese, C. R. (1994). The Ribosomal Database Project. Nucleic Acids Res 22, 3485-3487.

Makkar, N. S. \& Cross, T. (1982). Actinoplanetes in soil and on plant litter from freshwater habitats. $J$ Appl Bacteriol 52, 209-218.

Mikami, H. \& Ishida, Y. (1983). Post-column fluorometric detection of reducing sugars in high-performance liquid chromatography using arginine. Bunseki Kagaku 32, E207-E210.

Minnikin, D. E., O’Donnell, A. G., Goodfellow, M., Alderson, G., Athalye, M., Schaal, A. \& Parlett, J. H. (1984). An integrated procedure for the extraction of bacterial isoprenoid quinones and polar lipids. J Microbiol Methods 2, 233-241.

Pagani, H. \& Parenti, F. (1978). Kineosporia, a new genus of the order Actinomycetales. Int $J$ Syst Bacteriol 28, 401-406.

Raeder, U. \& Broda, P. (1985). Rapid preparation of DNA from filamentous fungi. Lett Appl Microbiol 1, 17-20.

Saito, H. \& Miura, K. (1963). Preparation of transforming deoxyribonucleic acid by phenol treatment. Biochim Biophys Acta 72, 619-629.

Saitou, N. \& Nei, M. (1987). The neighbor-joining method: a new method for reconstructing phylogenetic trees. Mol Biol Evol 4, 406-425.

Shirling, E. B. \& Gottlieb, D. (1966). Methods for characterization of Streptomyces species. Int J Syst Bacteriol 16, 313-340.

Stackebrandt, E., Kroppenstedt, R. M., Jahnke, K.-D., Kemmerling, C. \& Gürtler, H. (1994). Transfer of Streptosporangium viridogriseum (Okuda et al. 1966), Strepto- sporangium viridogriseum subsp. kofuense (Nonomura and Ohara 1969), and Streptosporangium albidum (Furumai et al. 1968) to Kutzneria gen. nov. as Kutzneria viridogrisea comb. nov., Kutzneria kofuensis comb. nov., and Kutzneria albida comb. nov., respectively, and emendation of the genus Streptosporangium. Int J Syst Bacteriol 44, 265-269.

Stackebrandt, E., Rainey, F. A. \& Ward-Rainey, N. L. (1997). Proposal for a new hierarchic classification system, Actinobacteria classis nov. Int J Syst Bacteriol 47, 479-491.

Staneck, J. L. \& Roberts, G. D. (1974). Simplified approach to identification of aerobic actinomycetes by thin-layer chromatography. Appl Microbiol 28, 226-231.

Stevenson, I. L. (1967). Utilization of aromatic hydrocarbons by Arthrobacter spp. Can J Microbiol 13, 205-211.

Suzuki, K. \& Komagata, K. (1983). Taxonomic significance of cellular fatty acid composition in some coryneform bacteria. Int J Syst Bacteriol 33, 188-200.

Suzuki, K., Sasaki, J., Uramoto, M., Nakase, T. \& Komagata, K. (1996). Agromyces mediolanus sp. nov., nom. rev., comb. nov., a species for "Corynebacterium mediolanum" Mamoli 1939 and for some aniline-assimilating bacteria which contain 2,4diaminobutyric acid in the cell wall peptidoglycan. Int $J$ Syst Bacteriol 46, 88-93.

Tamaoka, J. \& Komagata, K. (1984). Determination of DNA base composition by reversed-phase high-performance liquid chromatography. FEMS Microbiol Lett 25, 125-128.

Tamaoka, J., Katayama-Fujimura, Y. \& Kuraishi, H. (1983). Analysis of bacterial menaquinone mixtures by high performance liquid chromatography. $J$ Appl Bacteriol 54, 31-36.

Tomiyasu, I. (1982). Mycolic acid composition and thermally adaptative changes in Nocardia asteroides. J Bacteriol 151, 828-837.

Uchida, K. \& Aida, K. (1984). An improved method for the glycolate test for simple identification of the acyl type of bacterial cell walls. J Gen Appl Microbiol 30, 131-134.

Willoughby, L. G. (1969). A study on aquatic actinomycetes, the allochthonous leaf component. Nova Hedwigia 18, 45-113. 
